\title{
Prediksi Protein Target Bioaktif Ekstrak Metanol Buah Belimbing (Averrhoa carambola) dalam Regulasi Tekanan Darah
}

\author{
Siti Munawaroh ${ }^{1}$, Dian Laila Purwaningroom ${ }^{1 *}$, Dianita Rifqia Putri ${ }^{1}$, \\ Cholik Harun Rosjidi ${ }^{1}$ \\ ${ }^{1}$ Program Studi Keperawatan, Fakultas Ilmu Kesehatan Universitas Muhammadiyah Ponorogo \\ *E-mail: dianlaila87@gmail.com
}

\begin{abstract}
Blood pressure regulation is basically control of amount of blood flow to certain tissues according to their metabolic needs. The complexity of the mechanisms involved leading to the assumption that there are many functional and structural proteins involved in blood pressure regulation. Indonesian people, especially those living on the island of Java, usually consume star fruit Averrhoa carambola to reduce blood pressure, but the content of bioactive compounds and the mechanism of their interference with proteins is still unknown. This study aimed to determine the bioactive compound content of Averrhoa carambola's methanol extract and its mechanism of interference with the target proteins. An amount of $200 \mathrm{~g}$ Averrhoa carambola dried simplicia was extracted by the maceration method using absolute methanol. The extract was then subjected to phytochemical tests using the Gas Chromatography-Mass Spectrometry (GC-MS) method. Based on the results obtained from the GC-MS phytochemical test, the names of the bioactive compounds found in the Averrhoa carambola methanol extract were obtained. The compounds are then analyzed for their target protein in the human body using the STITCH database (http://stitch.embl.de/). The proteins that had been predicted to be the target of active compounds of Averrhoa carambola methanol extract were analyzed for interactions between proteins using the STRINGdb database (https://string-db.org/cgi/input.pl). Based on this research, it can be concluded that Averrhoa carambola fruit methanol extract can help lower blood pressure by producing $N O$ and acting as antioxidants. However, further research (in-vitro and in-vivo) needs to be done to prove the mechanism.
\end{abstract}

Keywords: protein target, Averrhoa carambola methanol extract, blood pressure regulation

\begin{abstract}
Abstrak
Regulasi tekanan darah adalah jumlah kontrol aliran darah ke jaringan tertentu sesuai dengan kebutuhan metabolismenya. Kompleksnya mekanisme yang terlibat, memunculkan asumsi terdapat banyak protein fungsional maupun struktural yang terlibat dalam regulasi tekanan darah. Masyarakat Indonesia, terutama yang tinggal di pulau Jawa biasa mengkonsumsi buah belimbing untuk menurunkan tekanan darah, namun kandungan senyawa bioaktif dan mekanisme intervensinya terhadap protein-protein belum diketahui. Tujuan penelitian ini adalah untuk mengetahui kandungan senyawa bioaktif ekstrak metanol buah Averrhoa carambola dan mekanisme intervensinya terhadap protein-protein targetnya. Simplisia kering buah Averrhoa carambola sebanyak $200 \mathrm{~g}$ diekstraksi dengan metode maserasi menggunakan metanol absolut. Dari ekstrak tersebut dilakukan uji fitokimia dengan metode Gas chromatography-mass spectrometry (GC-MS) sehingga didapatkan nama-nama senyawa bioaktif yang terdapat pada ekstrak metanol Averrhoa carambola. Senyawa-senyawa tersebut kemudian dianalisis protein targetnya dalam tubuh manusia menggunakan database STITCH (http://stitch.embl.de/). Kemudian dianalisis interaksi antar protein menggunakan database STRINGdb (https://string-db.org/cgi/input.pl). Berdasarkan penelitian ini, ekstrak metanol buah Averrhoa carambola dapat membantu menurunkan tekanan darah dengan memproduksi NO dan berperan sebagai antioksidan. Namun, penelitian lebih lanjut (in-vitro dan in-vivo) perlu dilakukan untuk membuktikan mekanismenya.
\end{abstract}

Kata Kunci: protein target, ekstrak metanol Averrhoa carambola, regulasi tekanan darah

\section{Pendahuluan}

Pada dasarnya, regulasi tekanan darah adalah kontrol jumlah aliran darah ke jaringan tertentu sesuai dengan kebutuhan metabolismenya. Mekanisme lokal yang mengontrol aliran darah termasuk vasokonstriksi dan dilatasi secara akut, dan kronis, perubahan jumlah dan kaliber pembuluh darah yang memasok jaringan. 
Sekresi autokrin endotel berperan penting dalam vasokonstriksi dan vasodilatasi. Terdapat berbagai mekanisme yang mendukung berlangsungnya sirkulasi darah, diantaranya adalah mekanisme neural, mekanisme renal endocrinehormonal, dan beberapa mekanisme hormonal yang lain ${ }^{1}$. Kompleksnya mekanisme yang terlibat, memunculkan asumsi terdapat banyak faktor yang terlibat dalam regulasi tekanan darah.

Hipertensi merupakan suatu penyakit di mana penderita mengalami tingginya tekanan darah, yaitu $>140 \mathrm{~mm} / \mathrm{Hg}^{2}$. Hipertensi telah menjadi permasalahan kesehatan global yang merupakan faktor resiko untuk penyakit penyakit berat, misalnya stroke, gagal ginjal, dan kematian mendadak. Setiap tahun, tercatat sekitar 9,4 juta penduduk dunia meninggal karena hipertensi ${ }^{3}$. Berdasarkan data Riset Kesehatan Dasar tahun 2018, prevalensi hipertensi dari penduduk usia lebih dari atau sama dengan 18 tahun tercatat $34,1 \%$, kasus yang paling tinggi terdapat di Kalimantan Selatan $(44,1 \%)^{4}$.

Berbagai terobosan dilakukan untuk dapat menemukan terapi hipertensi yang paling minim resiko dan efek samping, di antara menggunakan obat-obat dari bahan alam. Penggunaan bahan alam dalam terapi hipertensi diyakini memiliki efektifitas yang baik dengan resiko komplikasi dan efek samping yang minim. Namun selama ini belum dapat diketahui dengan pasti mekanisme antihipertensi dari bahan alam. Walau demikian, saat ini sudah dapat dilakukan prediksi kinerja suatu obat atau bioaktif dari suatu tumbuhan dalam sistem seluler tubuh manusia melalui metode komputasi sehingga dapat dipelajari target-target suatu bioaktif tersebut menggunakan software maupun penelusuran database. Software yang biasa digunakan dalam proses drug discovery diantaranya adalah PubChem, STITCH, STRINGdb, dan lainlain. PubChem merupakan database untuk berbagai senyawa kimia. STITCH merupakan database dan tool untuk menganalisis interaksi antara senyawa bioaktif dengan protein targetnya.

Masyarakat Indonesia terutama yang tinggal di pulau Jawa biasa mengkonsumsi buah belimbing (Averrhoa carambola) untuk menurunkan tekanan darah. Penelitian terdahulu menyatakan bahwa kemungkinan Averrhoa carambola dapat menginhibisi $\mathrm{Ca}(2+)$ dalam terapi hipertensi pada tikus, penelitian tersebut dilakukan melalui pendekatan in-vitro dan in-vivo ${ }^{5}$. Walau demikian, kandungan senyawa bioaktif dan mekanisme intervensinya terhadap molekul protein targetnya pada manusia belum diketahui. Oleh karena itu, penelitian ini bertujuan untuk mengetahui kandungan ekstrak metanol buah Averrhoa carambola beserta prediksi target dan interaksinya dalam penurunan tekanan darah.

\section{Metode}

Penelitian ini dilakukan di Balai Materia Medica Batu dan Laboratorium Biokomputasi Inbio Indonesia Malang pada bulan Mei hingga Agustus 2018.

Alat yang digunakan dalam ekstraksi dan uji fitokimia adalah beaker glass 3000 $\mathrm{ml}$ (Pyrex), rotary evaporator (Rotavapor R-300), dan Gas chromatography-mass spectrometry (GC-MS) (Thermo Scientific Dionex Ultimate 3000 RSLCnano with microflow meter). Alat yang digunakan dalam analisis protein target dan interaksinya adalah komputer, database STITCH (http://stitch.embl.de/), dan database STRINGdb (https://stringdb.org/cgi/input.pl). Molecular docking menggunakan software autodock4 algorithm using PyRx-0.8. ikatan antara ligan dan reseptor divisualisasikan menggunakan software Discovery studio.

Bahan yang digunakan dalam ekstraksi dan uji fitokimia adalah $200 \mathrm{~g}$ simplisia kering buah belimbing (Averrhoa carambola), metanol absolut sebanyak 3 L, rotary evaporator (Rotavapor R-300), 
dan GC-MS (Thermo Scientific Dionex Ultimate 3000 RSLCnano with microflow meter).

\section{Ekstraksi dan Uji Fitokimia}

Sampel pada penelitian ini adalah Averrhoa carambola, diambil bagian buahnya. Simplisia kering buah Averrhoa carambola didapat dari Balai Materia Medica Batu Jawa Timur. Sediaan 200 g simplisia kering buah Averrhoa carambola diekstraksi dengan metode maserasi dalam beaker glass menggunakan metanol absolut sebanyak 3 L selama 3 hari dalam suhu ruang. Ekstrak kemudian dipekatkan pada suhu $68^{\circ} \mathrm{C}$ menggunakan rotary evaporator untuk mendapatkan ekstrak kasar (crude extract). Semua ekstrak disimpan dalam wadah tertutup pada suhu $4^{\circ} \mathrm{C}$ hingga digunakan. Dari ekstrak tersebut kemudian dilakukan uji fitokimia dengan metode GC-MS.

\section{Analisis Protein Target dan Interaksinya.}

Berdasarkan hasil yang diperoleh dari uji fitokimia GC-MS didapatkan namanama senyawa bioaktif yang terdapat pada ekstrak metanol Averrhoa carambola. Senyawa-senyawa tersebut kemudian dianalisis protein targetnya dalam tubuh manusia menggunakan database STITCH (http://stitch.embl.de/). STITCH adalah database tentang interaksi yang telah diketahui dan diprediksi antara bahan kimia dan protein. Interaksi meliputi asosiasi langsung (fisik) dan tidak langsung (fungsional). Cara penggunaan STITCH adalah dengan memasukkan alamat website STITCH pada browser lalu pilih menu "search". Kemudian pilih menu "multiple names" untuk menginput lebih dari satu senyawa secara bersamaan. Pada kolom item name dimasukkan namanama senyawa yang ingin diketahui targetnya. Pada kolom organism dipilih Homo sapiens. Lalu klik "search" dan akan muncul daftar senyawa yang dikenali oleh sistem, kemudian pilih "continue" sehingga muncul interaksi antara senyawasenyawa kimia dengan protein-protein targetnya. Interaksi antara senyawa aktif dengan protein ini kemudian dianalisis afinitasnya menggunakan metode molecular docking. Protein-protein yang telah terprediksi menjadi target senyawa aktif ekstrak metanol buah Averrhoa carambola tersebut lalu dianalisis interaksi antar protein menggunakan database STRINGdb (https://string-db.org/cgi/ input.pl). Cara penggunaan STRINGdb adalah dengan memasukkan alamat website STRINGdb pada browser lalu pilih menu "search", lalu pilih menu "multiple protein" dan memasukkan nama-nama protein pada kolom "List of Protein". Pada kolom organism dipilih Homo sapiens. Lalu klik "search" dan akan muncul daftar protein yang dikenali oleh sistem, kemudian pilih "continue" sehingga muncul interaksi antar protein.

\section{Hasil}

Berdasarkan hasil uji fitokimia GC-MS diketahui setidaknya terdapat 11 macam senyawa bioaktif yang terkandung dalam ekstrak metanol buah Averrhoa carambola (Gambar 1 dan Tabel 1). 


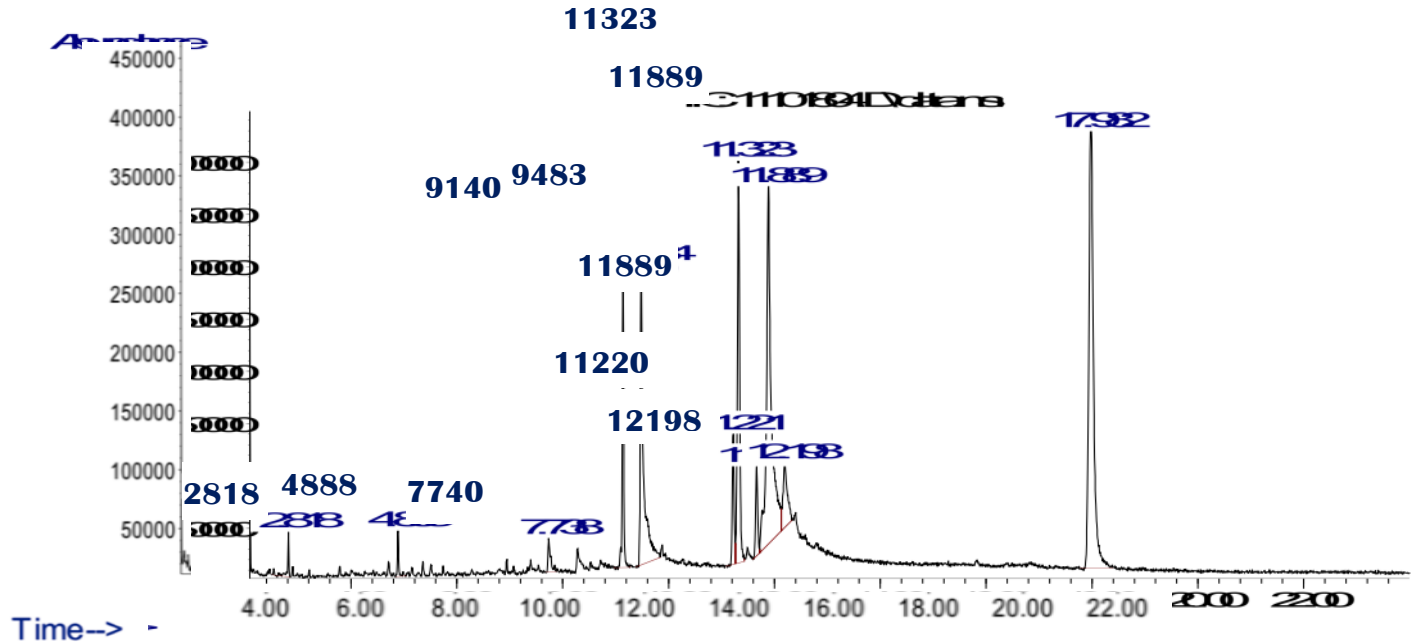

Gambar 1. Kromatogram Ekstrak Metanol Buah Averrhoa carambola dengan Metode GC-MS

Di antara 11 senyawa ini ternyata tidak semuanya berinteraksi secara langsung dengan protein. Hanya 2 senyawa aktif yang berinteraksi secara langsung dengan protein target, yaitu palmitate (CID 985) dan linolenic acid (CID 5280450) (Gambar 3A). Kedua senyawa ini berinteraksi setidaknya dengan O3FAR1, APOB, GCG, PPT1, PPARA, CPT2, CPT1A, ACACA, TRAPPC3, NOS3 (Gambar 3A), interaksi kesepuluh protein tersebut dapat dilihat pada gambar 3B.

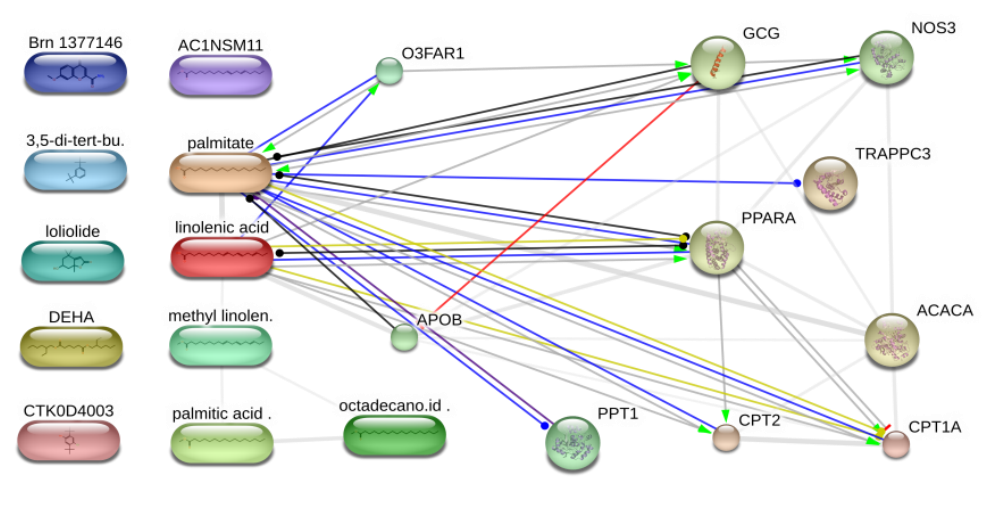

A

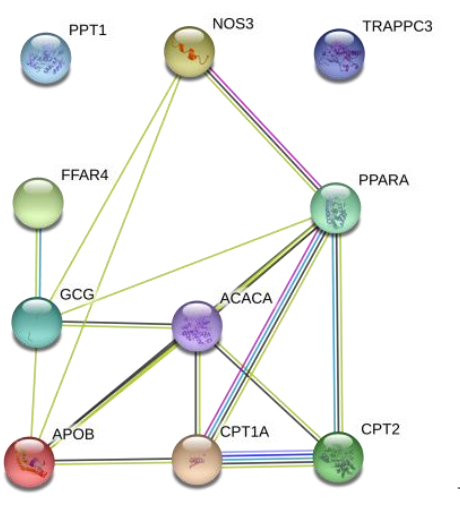

B

Gambar 2. A. Interaksi antara senyawa bioaktif ekstrak buah Averrhoa carambola dengan protein targetnya. Palmitate dan linoleic acid merupakan senyawa bioaktif yang paling banyak berinteraksi dengan protein-protein targetnya. B. Interaksi antar protein-protein target senyawa bioaktif ekstrak Averrhoa carambola. PPARA merupakan protein yang paling banyak berinteraksi dengan protein lain. 

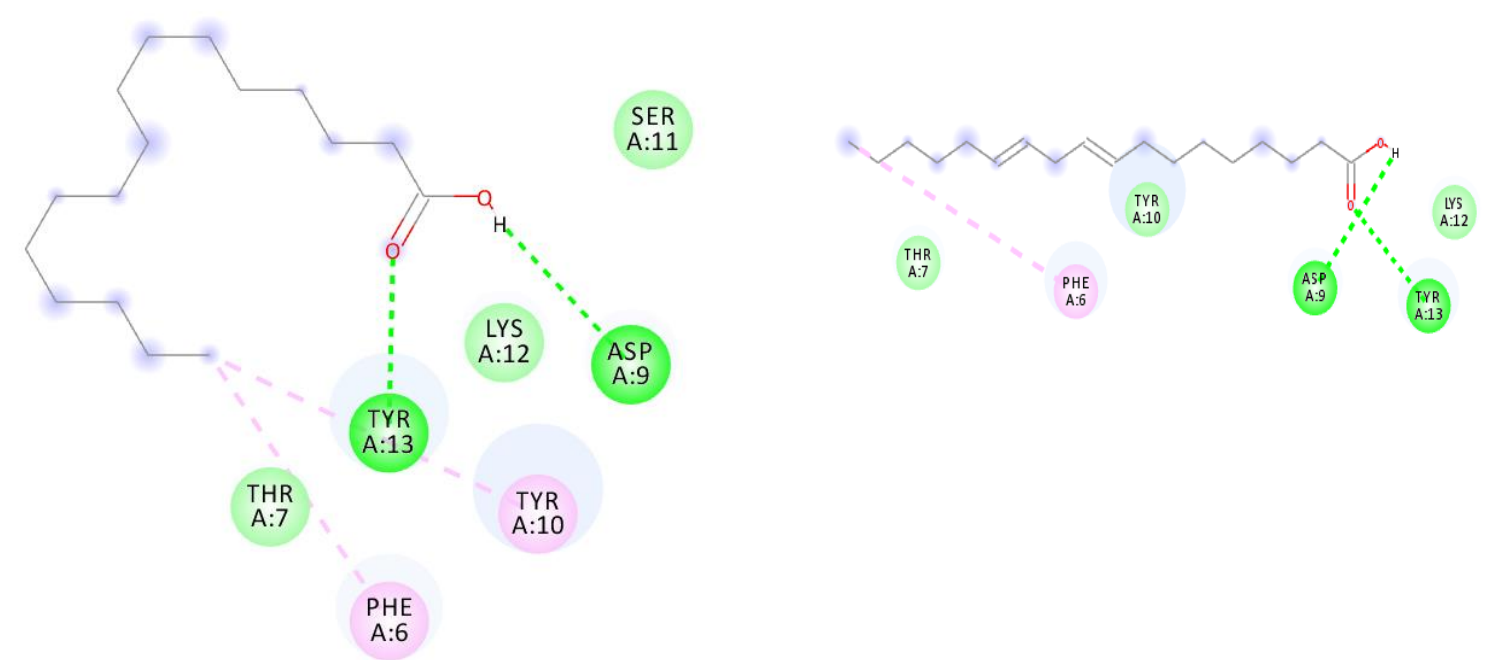

Interactions

$\square$ van der Waals $\quad \square$ Pi-Alkyl

A

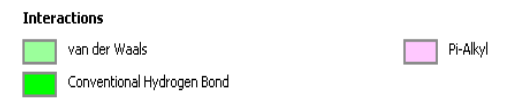

B

MET
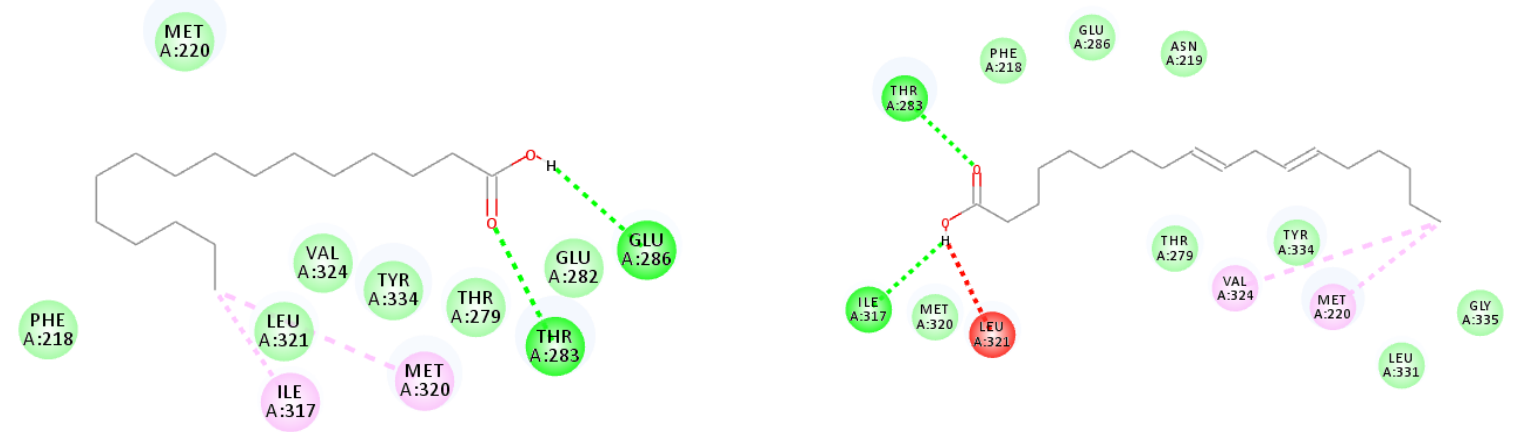

Interactions

$\square$ van der Waals
Conventional Hydrogen Bond

$\square$ Alkyl

Interactions
$\square$ van der Waals
$\square \quad$ Conventional Hydrogen Bond

$\square$ Unfavorable Donor-Donor
$\square$ Alkyl

C

D 

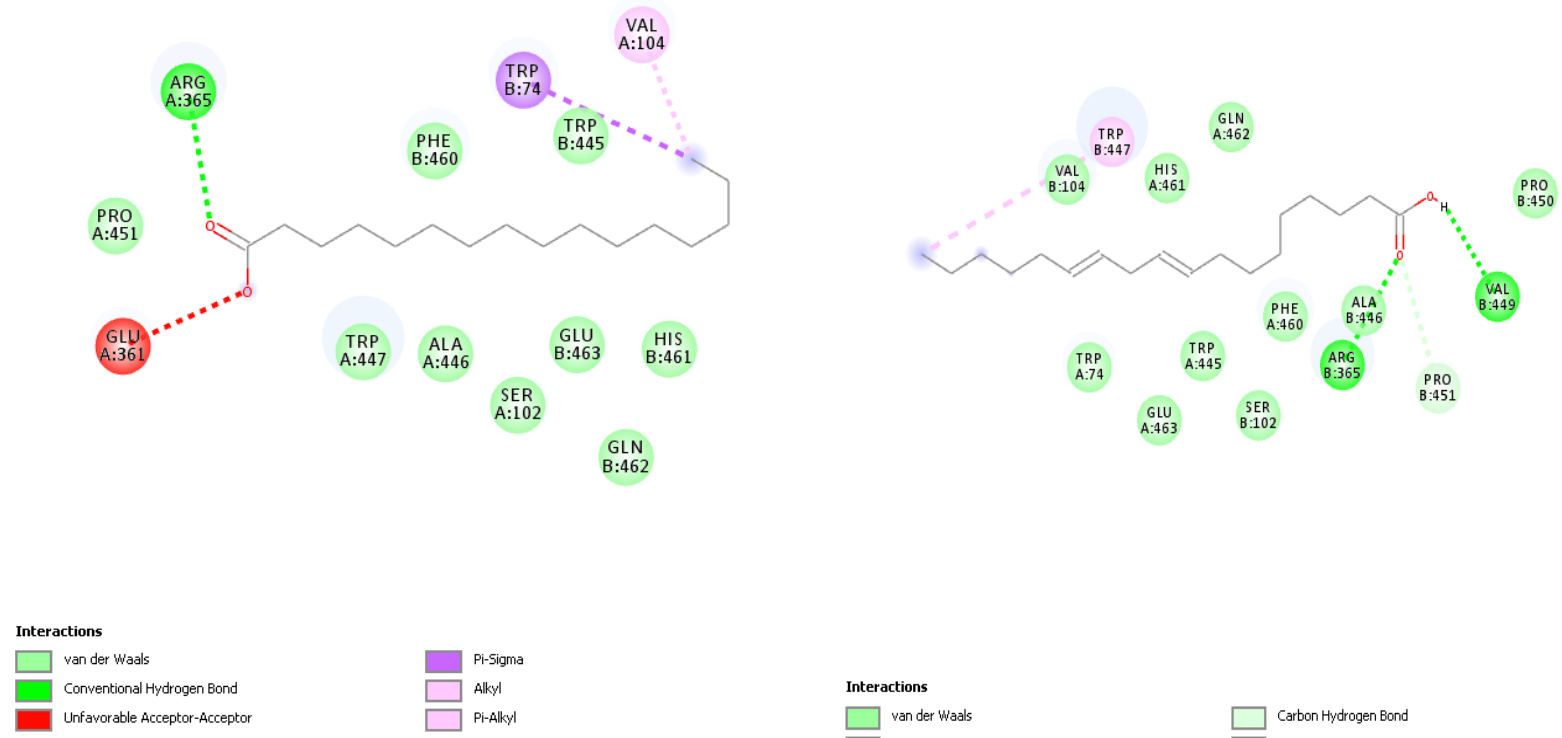

$\mathbf{E}$
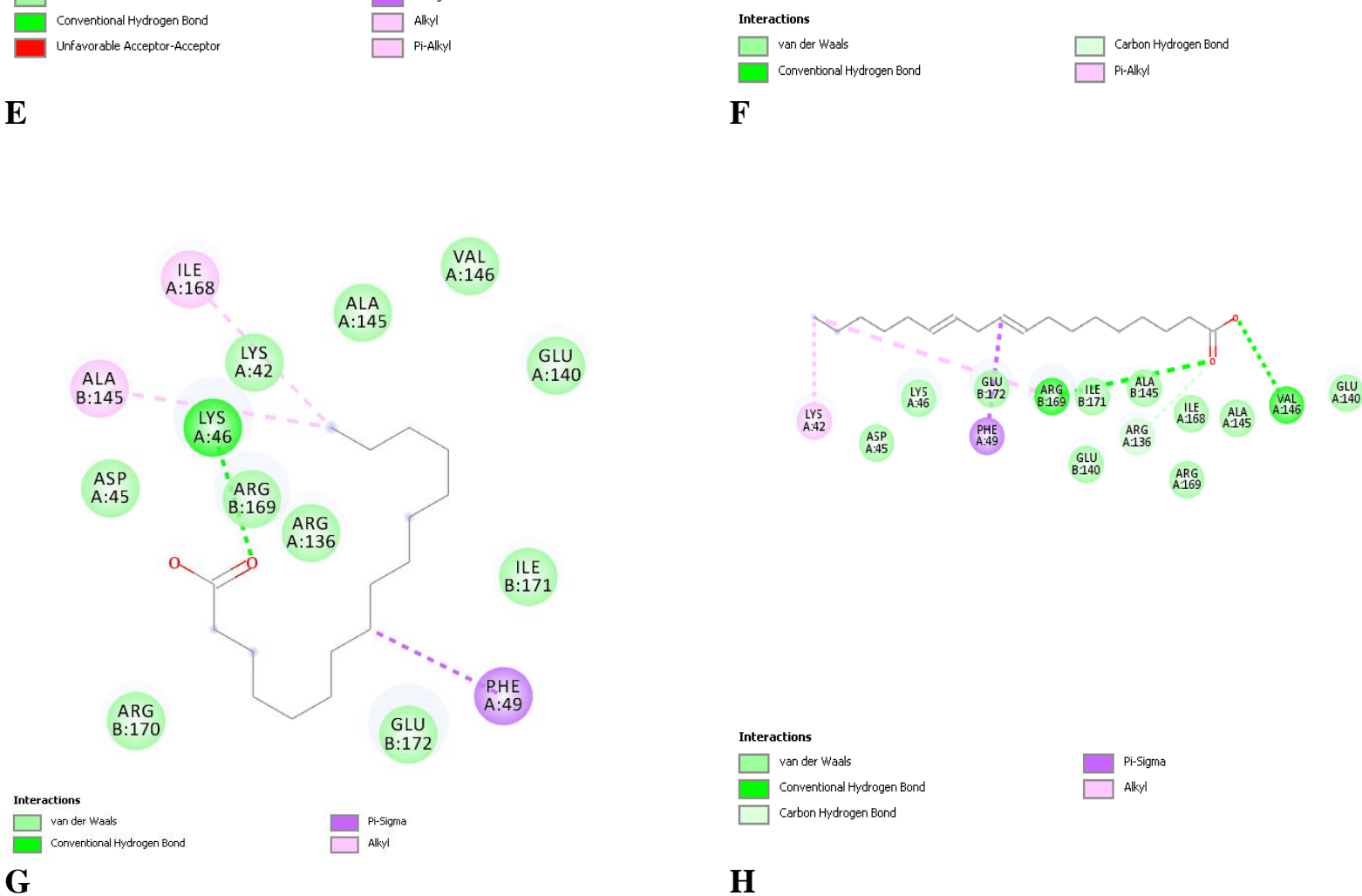

$\mathbf{H}$ 

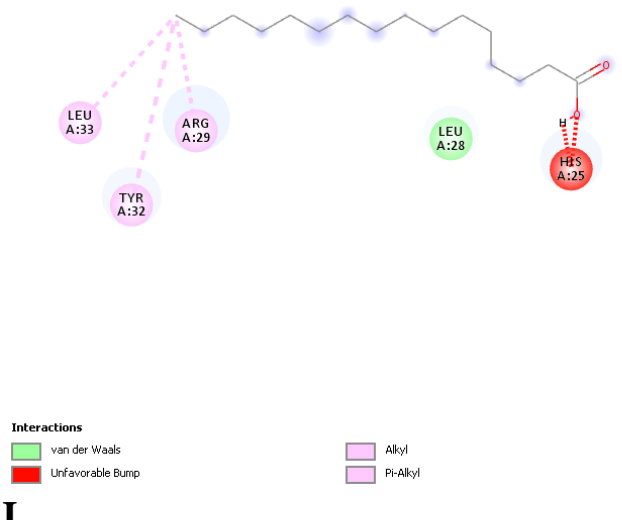

T:PRP
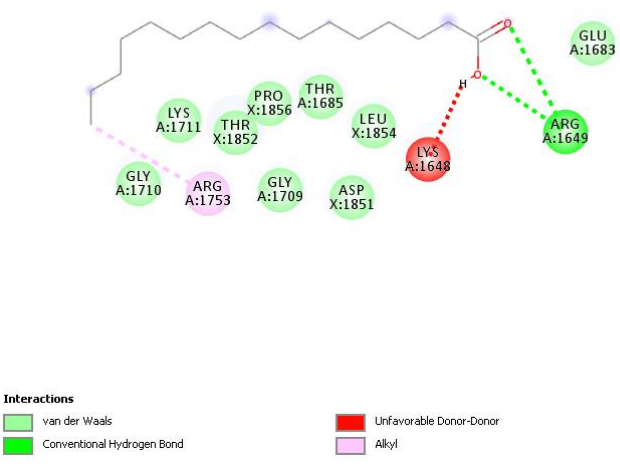

$\mathbf{K}$

Gambar 3. Interaksi antara protein ekstrak buah Averrhoa carambola.

A. Interaksi antara protein $1 \mathrm{BHO}$ dengan palmitate. B. Interaksi antara protein $1 \mathrm{BHO}$ dengan linoleic acid. C. Interaksi antara protein 1KKQ dengan palmitate. D. Interaksi antara protein $1 \mathrm{KKQ}$ dengan linoleic acid. E. Interaksi antara protein 1M9R dengan palmitate. F. Interaksi antara protein 1M9R dengan linoleic acid. G. Interaksi antara protein $2 \mathrm{CFH}$ dengan palmitate. $\mathrm{H}$. Interaksi antara protein $2 \mathrm{CFH}$ dengan linoleic acid. I. Interaksi antara protein 2LE3 dengan palmitate. J. Interaksi antara protein 2LE3 dengan linoleic acid. $\mathrm{K}$. Interaksi antara protein $3 \mathrm{COJ}$ dengan palmitate. L. Interaksi antara protein 3COJ dengan linoleic acid. 
Tabel 1. Nama senyawa bioaktif yang ditemukan dalam ekstrak metanol Averrhoa carambola

\begin{tabular}{|c|c|c|c|c|c|}
\hline No & Nama senyawa bioaktif & $\begin{array}{c}\text { RT } \\
\text { Area } \\
\%\end{array}$ & $\begin{array}{c}\text { Nama Senyawa } \\
\text { Berhasil Diinput di } \\
\text { STITCH }\end{array}$ & $\begin{array}{c}\text { Nama } \\
\text { Ditemukan di } \\
\text { Database } \\
\text { STITCH } \\
\end{array}$ & CID \\
\hline 1. & $\begin{array}{l}\text { Benzene, 1,3-bis(1,1- } \\
\text { dimethylethyl)- }\end{array}$ & 2.819 & 1014-60-4 & $\begin{array}{l}\text { 3,5-di-tert- } \\
\text { butylphenyl }\end{array}$ & $\underline{136810}$ \\
\hline 2. & $\begin{array}{l}\text { Phenol, 2,5-bis(1,1- } \\
\text { dimethylethyl) }\end{array}$ & 4.888 & $111342-06-4$ & CTKOD4003 & $\underline{14028656}$ \\
\hline 3. & $\begin{array}{l}\text { (-)-Loliolide } \$ \$ 2(4 H)- \\
\text { Benzofuranone, } 5,6,7,7 a- \\
\text { tetrahydro-6-hydroxy- } \\
\text { 4,4,7a-trimethyl-, }\end{array}$ & 7.740 & isololiolide & loliolide & $\underline{11019783}$ \\
\hline 4. & Hexadecanoic acid, methyl ester & 9.140 & methyl palmitate & $\begin{array}{l}\text { palmitic acid } \\
\text { methyl ester }\end{array}$ & $\underline{8181}$ \\
\hline 5. & n-Hexadecanoic acid & 9.483 & $\begin{array}{l}n \text {-Hexadecanoic } \\
\text { acid }\end{array}$ & palmitate & $\underline{985}$ \\
\hline 6. & $\begin{array}{l}\text { 10,13-Octadecadienoic acid, } \\
\text { methyl ester }\end{array}$ & 11.220 & SCHEMBL8659612 & ACINSM11 & $\underline{5365678}$ \\
\hline 7. & $\begin{array}{l}\text { 9,12,15-Octadecatrienoic acid, } \\
(Z, Z, Z) \text { - }\end{array}$ & 11.323 & linolenic acid & linolenic acid & $\underline{5280450}$ \\
\hline 8. & Octadenoic acid, methyl ester & 11.666 & methyl stearate & $\begin{array}{l}\text { octadecanoic } \\
\text { acid methyl } \\
\text { ester }\end{array}$ & $\underline{8201}$ \\
\hline 9. & $\begin{array}{l}\text { 9,12, 15-Octadecadienoic acid, } \\
\text { methyl ester, }(\mathrm{Z}, \mathrm{Z}, \mathrm{Z}) \text { - }\end{array}$ & 11.889 & methyl linolenate & $\begin{array}{l}\text { methyl } \\
\text { linolenate }\end{array}$ & $\underline{5319706}$ \\
\hline 10. & $\begin{array}{l}\text { Thiosulfuric acid (H2S2O3) S-(2- } \\
\text { aminoethyl) ester } \$ \$ \text { Thiosulfuric } \\
\text { acid, } S \text { - }(2 \text {-aminoethyl) ester } \$ \$ \\
\text { Cys teamine, } S \text {-sulfo- } \$ \$ \\
\text { Cysteaminesulfonic acid } \$ \$ \\
\text { S.beta-Aminoethylthiosulfuric } \\
\text { acid } \$ \$ \text { - }(2 \text {-Aminoethyl) } \\
\text { hydrogen thiosulfate } \$ \$ 2- \\
\text { Aminoethanethiol hydro }\end{array}$ & 12.198 & $54641-86-0$ & Brn 1377146 & $\underline{23668627}$ \\
\hline 11. & $\begin{array}{l}\text { Hexanedioic acid, bis( } 2- \\
\text { ethylhexyl) ester }\end{array}$ & 17.982 & $\begin{array}{l}\text { Diethylhexyl } \\
\text { adipate }\end{array}$ & DEHA & $\underline{7641}$ \\
\hline
\end{tabular}

Tabel 2. Energi Afinitas Ikatan antara senyawa pada ekstrak Averrhoa carambola dengan protein targetnya (dalam $\mathrm{kcal} / \mathrm{mol}$ )

\begin{tabular}{llllllll}
\hline & $1 \mathrm{bh} 0$ & $1 \mathrm{kkq}$ & $1 \mathrm{~m} 9 \mathrm{r}$ & $2 \mathrm{cfh}$ & $2 \mathrm{le} 3$ & $3 \mathrm{coj}$ & $3 \mathrm{gro}$ \\
\hline $\begin{array}{l}\text { linoleic } \\
\text { acid }\end{array}$ & $-4,7$ & $-5,8$ & $-6,6$ & $-6,6$ & $-4,9$ & $-5,2$ & $-4,1$ \\
\hline palmitate & $-4,4$ & $-5,5$ & $-6,5$ & $-5,8$ & $-3,3$ & $-4,9$ & $-4,5$ \\
\hline
\end{tabular}


Tabel 3. Interaksi antara senyawa pada ekstrak Averrhoa carambola dengan asam amino protein target berdasarkan hasil molecular docking pada gambar 3

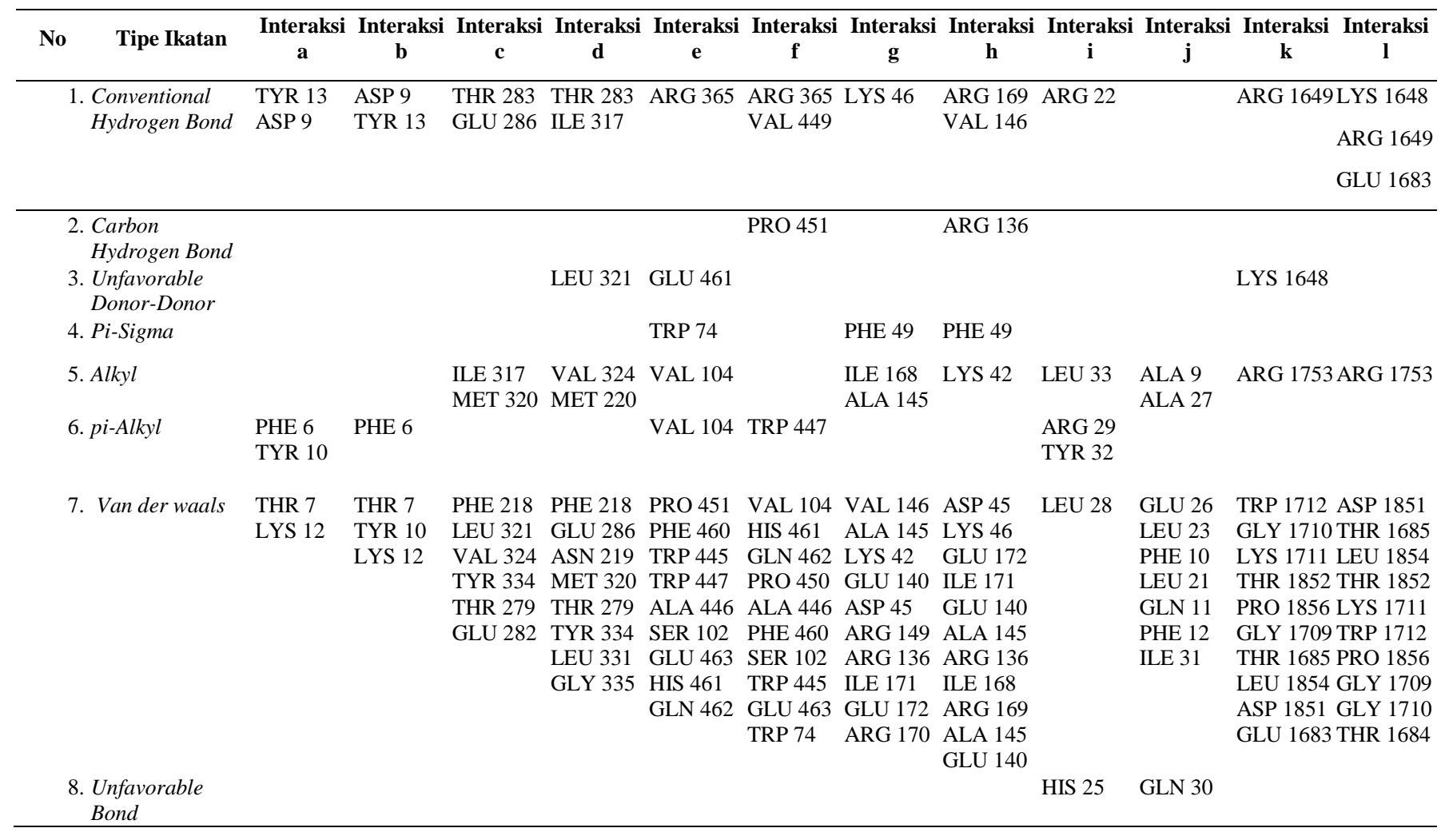

\section{Pembahasan}

Berdasarkan hasil uji fitokimia, terdapat 11 jenis senyawa dalam ekstrak metanol Averrhoa carambola. Benzene, 1,3bis(1,1-dimethylethyl)-(136810) termasuk dalam kelas senyawa organik yang dikenal sebagai fenilpropana yaitu senyawa organik yang mengandung bagian fenilpropana. Methyl hexadecanoic acid (8181) termasuk dalam kelas senyawa organik yang dikenal sebagai ester metil asam lemak yaitu senyawa yang mengandung asam lemak yang diesterifikasi dengan gugus metil. Mereka memiliki struktur umum RC $(=\mathrm{O})$ OR ', di mana $\mathrm{R}=$ ekor alifatik berlemak atau kelompok organyl dan $\mathrm{R}^{\prime}=$ kelompok metil. Asam heksadekanoat (985) adalah nama lain dari asam palmitat, asam lemak rantai panjang jenuh rantai lurus, enam belas karbon. Asam lemak ini memiliki peran sebagai EC 1.1.1.189 (prostaglandin-E2 9-reductase) inhibitor, metabolit tanaman, metabolit Daphnia magna dan metabolit alga. Ini adalah asam lemak rantai panjang dan asam lemak jenuh rantai lurus. Ini adalah asam konjugat heksadekanoat ${ }^{6}$.

Asam linoleat ( $\underline{5280450)}$ ) adalah asam lemak tak jenuh ganda, juga dikenal sebagai asam lemak omega-6, yang banyak terdapat pada glikosida tanaman. Dalam asam lemak tak jenuh ganda, particular polyunsaturated fatty acid (PUFA) memiliki ikatan rangkap pertama terletak di antara atom karbon keenam dan ketujuh dari ujung metil asam lemak (n-6). Asam linoleat adalah asam lemak esensial dalam nutrisi manusia karena tidak dapat disintesis oleh manusia. Ini digunakan dalam biosintesis prostaglandin (melalui asam arakidonat) dan membran sel. Asam linoleat ditemukan berhubungan dengan asidemia isovalerik, yang merupakan kesalahan metabolisme bawaan. Metil stearat (201) adalah ester metil asam lemak dan ester oktadekanoat. Ia memiliki peran sebagai metabolit ${ }^{6}$. 
Metil linolenat (5319706) adalah ester metil asam lemak yang berasal dari asam alfa-linolenat. Dalam tubuh tumbuhan, zat ini memiliki peran sebagai metabolit dan penarik serangga. Zat ini berasal dari asam alfa-linolenat. Bis (2-ethylhexyl) adipate adalah diester yang dihasilkan dari kondensasi formal gugus karboksi asam adipat dengan 2-ethylhexan-1-ol. Senyawa ini adalah diester, ester karboksilat dan anggota asam dikarboksilat dan turunan tersubstitusi-O. Senyawa berasal dari 2ethylhexan-1-ol dan asam adipat ${ }^{6}$.

Pada gambar 3A, nampak adanya hasil analisis STITCH yang merupakan interaksi antara senyawa bioaktif dengan protein targetnya. Terlihat bahwa palmitate dan linoleic acid yang paling banyak berinteraksi dengan protein targetnya. Di antara jenis-jenis interaksi tersebut antara lain adalah aktivasi (hijau), binding (biru), fenotip (biru muda), reaksi (hitam), inhibisi (merah), katalisis (ungu), post translational modification (merah muda), dan transcriptional regulation (kuning). Diantara 11 senyawa yang ditemukan ada dalam ekstrak metanol buah Averrhoa carambola ternyata tidak semuanya berinteraksi secara langsung dengan protein targetnya. Hanya 2 senyawa aktif yang berinteraksi secara langsung dengan protein targetnya, yaitu palmitate (CID 985) dan linolenic acid (CID 5280450) (Gambar 3A). Palmitate merupakan salah satu jenis asam lemak jenuh yang mencapai $20-30 \%$ dari total asam lemak di dalam tubuh $^{7}$, dan linoleic acid merupakan asam lemak esensial tak jenuh ganda yang banyak ditemukan dalam minyak nabati. Ini digunakan dalam biosintesis prostaglandin dan membran $\mathrm{sel}^{8}$.

Kedua senyawa palmitate dan linoleic acid ini berinteraksi setidaknya dengan O3FAR1, APOB, GCG, PPT1, PPARA, CPT2, CPT1A, ACACA, TRAPPC3, NOS3 (Gambar 3A), interaksi kesepuluh protein tersebut dapat dilihat pada gambar 3B. Palmitate berinteraksi dengan O3FAR1, APOB, GCG, PPT1, PPARA,
CPT2, CPT1A, ACACA, TRAPPC3, NOS3. Sedangkan linoleic acid berinteraksi dengan O3FAR1, APOB, GCG, PPT1, PPARA, CPT2, CPT1A. Interaksi antara palmitate (CID 985) dan linolenic acid (CID 5280450) dengan protein-protein targetnya menunjukkan bahwa IM9R dengan linoleic acid memiliki energi afinitas terendah yaitu $-6,6$ (Gambar 3 dan tabel 2). O3FAR1 setidaknya memiliki 4 nama lain pada gennya, yaitu FFAR4 GPR120, GPR129, PGR4. Gen O3FAR1 menyandi free fatty acid receptor 4 . Asam lemak bebas (FFA) menyediakan sumber energi yang penting dan juga bertindak sebagai pensinyalan molekul dalam berbagai proses seluler, termasuk sekresi peptida usus incretin. Asam alfa-linolenat FFA menstimulasi sekresi peptida seperti glukagon (GLP-1) dari saluran gastro-intestinal. Protein ini berperan penting dalam patofisiologi diabetes ${ }^{9}$.

APOB merupakan gen penyandi Apolipoprotein B, protein ini adalah konstituen protein utama dari kilomikron (apo B-48), LDL (apo B-100) dan VLDL (apo B-100). Apo B-100 berfungsi sebagai sinyal pengenalan untuk pengikatan seluler dan internalisasi partikel LDL oleh reseptor apoB/E. Protein target selanjutnya yaitu GCG (Glucagon). Glukagon memainkan peran penting dalam metabolisme glukosa dan homeostasis. Dalam mengatur glukosa darah, glukagon meningkatkan glukoneogenesis dan mengurangi glikolisis. Hormon insulin melawan regulasi, meningkatkan kadar glukosa plasma sebagai respons terhadap hipoglikemia yang diinduksi insulin. Hormon ini berperan penting dalam memulai dan mempertahankan kondisi hiperglikemik pada diabetes. Saat ini, lipoprotein yang mengandung kolesterol, apolipoprotein B (apoB) diterima secara luas sebagai agen penyebab paling penting dari penyakit kardiovaskular aterosklerotik. Beberapa garis bukti yang tegas dan ortogonal semuanya bertemu pada lipoprotein densitas rendah dan 
partikel terkait sebagai aktor utama dalam genesis arterosklerosis ${ }^{10}$.

PPT1 adalah gen untuk protein palmitoyl-protein thioesterase 1 yang menghapus gugus asil lemak terkait dengan tioester seperti palmitat dari residu sistein yang dimodifikasi dalam protein atau peptida selama degradasi lisosom dengan panjang rantai asil 14 sampai 18 karbon. PPARA, peroxisome proliferator activated receptor alpha, adalah gen yang paling banyak diekspresikan di ginjal, jantung, hati, dan usus besar ${ }^{11}$. Peroxisome proliferator meliputi obat hipolipidemik, herbisida, antagonis leukotrien, dan plastisator karena dapat mendorong peningkatan ukuran dan jumlah peroksisom. Peroksisom adalah organel subselular yang ditemukan pada tumbuhan dan hewan yang mengandung enzim untuk respirasi dan untuk metabolisme kolesterol dan lipid. Tindakan proliferator peroksisom diperkirakan dimediasi melalui reseptor spesifik, yang disebut PPAR, yang termasuk dalam superfamili reseptor hormon steroid. PPAR memengaruhi ekspresi gen target yang terlibat dalam proliferasi sel, diferensiasi sel, dan respons imun serta inflamasi. Tiga subtipe terkait erat (alfa, beta/delta, dan gamma) telah diidentifikasi. Gen ini menyandikan subtipe PPAR-alfa, yang merupakan faktor transkripsi nuklear. PPAR memiliki peran sentral dalam regulasi glukosa dan homeostasis lipid melalui fungsinya sebagai sensor molekuler yang merespons ligan endogen, yang mengarah pada modulasi ekspresi gen. PPAR juga mengatur proliferasi sel, diferensiasi dan peradangan $^{12}$.

CPT2 adalah gen untuk protein enzim Carnitine O-palmitoyltransferase 2, mitokondria, ini terlibat dalam jalur betaoksidasi asam lemak, yang merupakan bagian dari metabolisme lipid. CPT1A, carnitine palmitoyltransferase 1A (liver); Protein ini terlibat dalam jalur betaoksidasi asam lemak, yang merupakan bagian dari metabolisme lipid, mengkatalisasi transfer gugus asil dari asam lemak rantai panjang-CoA terkonjugasi ke karnitin, yang merupakan langkah penting untuk penyerapan asam lemak rantai panjang dalam mitokondria dan beta-oksidasi berikutnya. Protein ini juga berperan penting dalam metabolisme trigliserida ${ }^{13}$. ACACA adalah acetyl-CoA carboxylase alpha dapat mengkatalisis reaksi pembatasan tingkat dalam biogenesis asam lemak rantai panjang. Melaksanakan tiga fungsi yaitu sebagai protein pembawa biotin karboksil, biotin karboksilase dan karboksiltransferase ${ }^{14}$. Trafficking protein particle complex 3 (TRAPPC3) adalah kompleks partikel protein yang berperan dalam transportasi vesikuler dari retikulum endoplasma ke Golgi ${ }^{15}$.

Target selanjutnya yaitu NOS3. NOS3 adalah nitric oxide synthase 3 yang berfungsi untuk memproduksi nitric oxide (NO). NOS3 merupakan nama lain dari eNOS, suatu enzim yang berperan penting dalam memproduksi NO yang berperan penting dalam regulasi vascular tone, proliferasi sel, adhesi leukosit, dan agregasi platelet ${ }^{16}$. Diproduksi di sel endotel, NO berdifusi melalui membran sel vascular smooth muscle dan mengaktifkan enzim guanylate cyclase (sGC), mengkatalisis konversi guanosine triphosphate menjadi cyclic guanosine monophosphate (cGMP) $)^{17}$ kemudian cGMP mengaktifkan G Kinase Protein (PKG) yang mengawali fosforilasi target seluler dengan mengurangi konsentrasi $\mathrm{Ca}^{2+}$ seluler yang mengakibatkan relaksasi vaskuler $^{18}$. Selain fungsi-fungsi ini, NO, memiliki sifat antioksidan dengan menginduksi ekspresi superoxcyde dismutase mengkatalisis konversi anion superoksida menjadi hidrogen peroksida 19

Interaksi yang lebih detil pun telah kami investigasi dengan metode molecular docking (Tabel 3), pendekatan ini dapat digunakan untuk memodelkan interaksi antara small molecule dan protein pada 
level atom ${ }^{20}$. Interaksi antara protein $1 \mathrm{BHO}$ dengan palmitate (interaksi a), palmitate membentuk ikatan hidrogen dengan asam amino TYR 13 dan ASP 9, ikatan py-Alkil dengan asam amino PHE 6 dan TYR 10, dan ikatan Van der waals dengan asam amino THR 7 dan LYS 12. Interaksi antara protein $1 \mathrm{BHO}$ dengan linoleic acid (interaksi b), linoleic acid membentuk ikatan hidrogen dengan ASP 9 dan TYR 13, ikatan py-Alkyl dengan PHE 6, dan ikatan Van der waals dengan THR 7, TYR 10, dan LYS 12. Interaksi antara protein $1 \mathrm{KKQ}$ dengan palmitate (interaksi c), palmitate membentuk ikatan hidrogen THR 283 dan GLU 286, ikatan alkil dengan ILE 317 dan MET 320, dan ikatan Van der waals dengan PHE 218, LEU 321, VAL 324, TYR 334, THR 279, dan GLU 282. Interaksi antara protein $1 \mathrm{KKQ}$ dengan linoleic acid (interaksi d), linoleic acid membentuk ikatan hidrogen dengan THR 283 dan ILE 317, ikatan unfavorable donor dengan LEU 321, alkyl VAL 324 dan MET 220, dan ikatan Van der waals dengan HE 218, GLU 286, ASN 219, MET 320, THR 279, TYR 334, LEU 331, dan GLY 335.

Interaksi antara protein 1M9R dengan palmitate (interaksi e), palmitate membentuk ikatan hidrogen dengan ARG 365, ikatan unfavorable donor-donor dengan GLU 461, ikatan pi-sigma dengan TRP 74, ikatan alkyl dengan VAL 104, ikatan pi-alkyl VAL 104, dan ikatan Van der waals dengan PRO 451, PHE 460, TRP 445, TRP 447, ALA 446, SER 102, GLU 463, HIS 461, dan GLN 462. Interaksi antara protein $1 \mathrm{M} 9 \mathrm{R}$ dengan linoleic acid (interaksi f), linoleic acid membentuk Ikatan hidrogen dengan ARG 365 dan VAL 449, ikatan carbon hidrogen bond dengan PRO 451, ikatan pi-alkyl dengan TRP 447, dan ikatan Van der waals dengan VAL 104, HIS 461, GLN 462, PRO 450, ALA 446, PHE 460, SER 102, TRP 445, GLU 463, dan TRP 74. Interaksi antara protein $2 \mathrm{CFH}$ dengan palmitate (interaksi g), palmitate membentuk ikatan hidrogen dengan LYS 46, ikatan pi-sigma dengan PHE 49, ikatan alky dengan 1 ILE 168 dan ALA 145, ikatan Van der waals dengan VAL 146, ALA 145, LYS 42, GLU 140, ASP 45, ARG 149, ARG 136, ILE 171, GLU 172, dan ARG 170. Interaksi antara protein $2 \mathrm{CFH}$ dengan linoleic acid (interaksi h), linoleic acid membentuk ikatan hidrogen dengan ARG 169 dan VAL 146, ikatan carbon hidrogen bond dengan ARG 136, ikatan pi-sigma dengan PHE 49, ikatan alkyl dengan LYS 42, ikatan Van der waals dengan ASP 45, LYS 46, GLU 172, ILE 171, GLU 140, ALA 145, ARG 136, ILE 168, ARG 169, ALA 145, dan GLU 140.

Interaksi antara protein 2LE3 dengan palmitate (interaksi i), palmitate membentuk ikatan hidrogen dengan ARG 22, ikatan alkil dengan LEU 33, ikatan pialkyl dengan ARG 29 dan TYR 32, ikatan Van der waals dengan LEU 28, ikatan unfavorable bond dengan HIS 25. Interaksi antara protein 2LE3 dengan linoleic acid (interaksi j), linoleic acid membentuk ikatan alkyl dengan ALA 9 dan ALA 27, ikatan Van der waals dengan GLU 26, LEU 23, PHE 10, LEU 21, GLN 11, PHE 12, ILE 31, dan ikatan unfavorable bond dengan GLN 30. Interaksi antara protein 3COJ dengan palmitate (interaksi $\mathrm{k}$ ), palmitate membentuk ikatan hidrogen dengan ARG 1649, ikatan unfavorable donor-donor dengan LYS 1648, ikatan alkil dengan ARG 1753, ikatan Van der waals dengan TRP 1712, GLY 1710, LYS 1711, THR 1852, PRO 1856, GLY 1709, THR 1685, LEU 1854, ASP 1851, dan GLU 1683. Interaksi antara protein 3COJ dengan linoleic acid (interaksi 1), linoleic acid membentuk ikatan hidrogen dengan LYS 1648, ARG 1649, GLU 1683, ikatan alkyl dengan ARG 1753, ikatan Van der waals dengan ASP 1851, THR 1685, LEU 1854, THR 1852, LYS 1711, TRP 1712, PRO 1856, GLY 1709, GLY 1710, dan THR 1684.

Berdasarkan hasil penelitian ini, menunjukkan bahwa buah belimbing 
memiliki berbagai senyawa aktif yang bersifat multi target. Ini merupakan keuntungan jika dibandingkan dengan obat hipertensi yang hanya memiliki target protein spesifik di dalam tubuh manusia yang dapat mengakibatkan efek samping yang signifikan akibat intervensi yang berlebihan pada protein yang menjadi target obat. Ekstrak tumbuhan dapat bekerja secara sistemik, dan meminimalkan efek samping dan komplikasi yang sering terjadi selama pengobatan hipertensi menggunakan obat.

\section{Kesimpulan}

Ekstrak metanol dari buah Averrhoa carambola dapat membantu menurunkan tekanan darah. Diprediksi bahwa beberapa senyawa aktif yang dimiliki tanaman ini berfungsi sebagai pengatur tekanan darah dengan menghambat memproduksi NO dan berperan sebagai antioksidan. Namun, penelitian lebih lanjut (in-vitro dan invivo) perlu dilakukan untuk membuktikan mekanismenya.

\section{Daftar Rujukan}

1. Chopra S, Baby C, Jacob JJ. Neuro-endocrine regulation of blood pressure. Indian $J$ Endocrinol Metab. 2011;15:281-288. doi:10.4103/2230-8210.86860

2. Vikrant S, Tiwari S. Essential Hypertension Pathogenesis and Pathophysiology. Indian Acad Clin Med. 2001;2:140-161.

3. WHO. A Global Brief on Hypertension. Switzerland: WHO Press; 2013.

4. HASIL UTAMA RISET KESEHATAN DASAR (Riskesdas) 2018. Jakarta: Badan Penelitian dan Pengembangan Kesehatan; 2018.

5. Soncini R, Santiago MB, Orlandi L, et al. Hypotensive effect of aqueous extract of Averrhoa carambola L. (Oxalidaceae) in rats: an in vivo and in vitro approach. $J$ Ethnopharmacol. 2011;133(2):353-357. doi:10.1016/j.jep.2010.10.001

6. Kim S, Chen J, Cheng T, et al. PubChem 2019 update: improved access to chemical data. Nucleic Acids Res. 2019;47(D1):D1102-D1109. doi:10.1093/nar/gky1033
7. Carta G, Murru E, Banni S, Manca C. Palmitic acid: Physiological role, metabolism and nutritional implications. Front Physiol. 2017;8(NOV). doi:10.3389/fphys.2017.00902

8. Kaur N, Chugh V, Gupta AK. Essential fatty acids as functional components of foods- a review. J Food Sci Technol. 2014;51(10):22892303. doi:10.1007/s13197-012-0677-0

9. Hirasawa A, Tsumaya K, Awaji T, et al. Free fatty acids regulate gut incretin glucagon-like peptide-1 secretion through GPR120. Nat Med. 2005;11(1):90-94. doi:10.1038/nm1168

10. Shapiro MD, Fazio S. Apolipoprotein Bcontaining lipoproteins and atherosclerotic cardiovascular disease. F1000Research. 2017. doi:10.12688/f1000research.9845.1

11. Fagerberg L, Hallstro M, Oksvold P, et al. Analysis of the Human Tissue-specific Expression by Genome-wide Integration of Transcriptomics and Antibody-based. Mol Cell Proteomics. 2014;13(2):397-406. doi:10.1074/mcp.M113.035600

12. Peters JM, Shah YM, Gonzalez FJ. The role of peroxisome proliferator-activated receptors in carcinogenesis and chemoprevention. Nat Rev Cancer. 2012. doi:10.1038/nrc3214

13. Bonnefont J-P, Djouadi F, Prip-Buus C, Gobin S, Munnich A, Bastin J. Carnitine palmitoyltransferases 1 and 2: biochemical, molecular and medical aspects. Mol Aspects Med. 2004;25(5-6):495-520. doi:10.1016/j.mam.2004.06.004

14. Colbert CL, Kim C-W, Moon Y-A, et al. Crystal structure of Spot 14, a modulator of fatty acid synthesis. Proc Natl Acad Sci U S A. 2010;107(44):18820-18825. doi:10.1073/pnas.1012736107

15. Vaca Jacome AS, Rabilloud T, Schaeffer-Reiss $\mathrm{C}$, et al. N-terminome analysis of the human mitochondrial proteome. Proteomics. 2015;15(14):2519-2524. doi:10.1002/pmic.201400617

16. Förstermann U, Münzel T. Endothelial Nitric Oxide Synthase in Vascular Disease. Circulation. 2006;113(13):1708-1714. doi:10.1161/CIRCULATIONAHA.105.602532

17. Denninger JW, Marletta MA. Guanylate cyclase and the $\cdot \mathrm{NO} / \mathrm{cGMP}$ signaling pathway. Biochim Biophys Acta - Bioenerg. 1999;1411(23):334-350. doi:10.1016/S0005- 
18. Surks HK, Mochizuki N, Kasai Y, et al. Regulation of Myosin Phosphatase by a Specific Interaction with cGMP- Dependent Protein Kinase I $\alpha$. Science (80- ). 1999;286(5444):1583-1587.

doi:10.1126/SCIENCE.286.5444.1583

19. Fukai T, Siegfried MR, Ushio-Fukai M, Cheng Y, Kojda G, Harrison DG. Regulation of the vascular extracellular superoxide dismutase by nitric oxide and exercise training. J Clin Invest. 2000;105(11):1631-1639. doi:10.1172/JCI9551

20. Meng X-Y, Zhang H-X, Mezei M, Cui M. Molecular Docking: A Powerful Approach for Structure-Based Drug Discovery. Curr Comput Aided-Drug Des. 2012;7(2):146-157. doi:10.2174/157340911795677602 